\title{
A breakthrough in landscape design: from traditional garden of ancient despots to the avant-garde "garden of Cubism"
}

\author{
Mykola Dyomin $^{1}$, Denys Chernyshev ${ }^{1}$, Andrii Dmytrenko ${ }^{2}$, Tetiana Kuzmenko², Peng Chang ${ }^{1}$ \\ ${ }^{1}$ Kyiv National University of Construction and Architecture, Ukraine \\ ${ }^{2}$ National University "Yuri Kondratyuk Poltava Polytechnic", Ukraine
}

\begin{abstract}
The article traces the process of moving away from traditional landscaping with millennial traditions to the revolutionary breakthrough of the 1920s, based on the views of the avant-garde and Cubism. One of the oldest traditional examples is the Chinese Garden, whose principles have been developed and refined over the millennia. In the Chinese garden and the natural environment in general, architecture played a secondary role, only emphasizing the beauty of the landscapes. It was the natural environment that dictated appearance of small architectural forms pavilions and arbours, their sizes, silhouettes and colouristic solution. The maximum conservation of natural landscapes without human intervention was aimed at the so-called landscape English garden. Instead, the French garden was aimed at improving the natural environment of man, that is, the parks are provided with regular planning, the introduction of green with molded crowns, flower beds with a complex pattern, widely used included in the regular composition fountains. All of these techniques were discarded in the early twentieth century, when, in parallel with the revolutionary changes in urban planning and architecture, there were dramatic changes in landscape design. In the so-called "garden of Cubism" of the period of constructivism-avant-garde, the natural environment no longer plays a major role, such a role is taken over by architecture and sculptural forms, and the garden is actually transformed into an installation.
\end{abstract}

Keywords: tradition, avant-garde constructivism, cubism, landscape design

\section{Introduction}

Since the appearance of the garden/park as a separate object, we can trace the development of its three main functions: utilitarian, symbolic and artistic. Also, the emergence of a garden / park as an object of landscape design is impossible without artificial elements introduced into the natural environment. The ratio of artificial and natural in the structure of a garden / park also changed at different times and in different countries.

Despite the differences associated with climatic conditions, historical events, cultural and artistic traditions, it can be argued that in fact until the 1920s, that is, before the period of constructivism and avant-guard, approaches in the landscape design remained hereditary and traditional.

The first systematically organized examples of landscape design emerged in ancient Egypt and Assyria, especially this trend has evolved since ancient times and in China. Landscape design in European countries in the past centuries is most often associated with landscape art of two types - French based on regularity and English based on natural picturesqueness.

Urban development in the late 19th and early 20th centuries clearly showed that the traditional concept of an urban garden / park as a green island in an urban environment could not provide favorable conditions for most citizens and should therefore be replaced by the concept of integrated urban landscaping. This made the utilitarian component of the garden's function optional and paved the way for the emergence of the "garden of Cubism", which is perceived almost exclusively as an art object, and most of the living plants in it have been replaced by artificial installations.
Despite the visual avant-gardism, such a garden can also be considered a creative rethinking of previous landscape trends, namely the French regular park. The basis of the "garden of Cubism" is partly the philosophy of French regular park, with the principles of emphasized geometry, creation of deep perspective views and human dominance over nature. The same signs are present in the gardens of Cubism, albeit on a different compositional basis, in other forms and in other materials. The "garden of Cubism" can be considered a turning point in the history of landscape design, which reflected the changes that took place in society in modern times and were also reflected in art and architecture.

Today, landscape design is developing in many directions, and one of the areas is the "modernist garden". Its difference from traditional landscape design, where architecture, small forms complement the beauty of natural environment, is that natural environment no longer plays a major role, and the garden itself begins to resemble not a landscape, but a work of art. Under the influence of modernist views, the attitude towards the notion of artificial garden was transformed during the twentieth century. It turns into a garden installation, then into a garden sculpture.

\section{Matherials and Methods}

For the study, the authors drew on sources that highlight the diversity of approaches in landscape design. The works devoted to general questions of landscape design were analyzed $[4 ; 11 ; 12 ; 14]$. It was used as a basic publication on Chinese traditional 


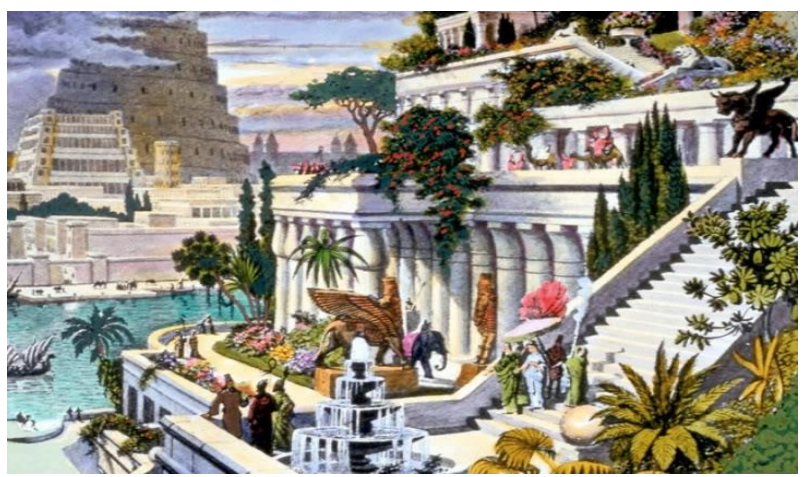

Fig. 1. Hanging Gardens of Babylon (Semiramis' gardens). This hand-coloured engraving, probably made in the 19th century after the first excavations in the Assyrian capitals, depicts the fabled

Hanging Gardens, with the Tower of Babel in the background.

Source:https://en.wikipedia.org/wiki/Hanging_Gardens_of_Babylo n\#/media/File:Hanging_Gardens_of_Babylon.jpg

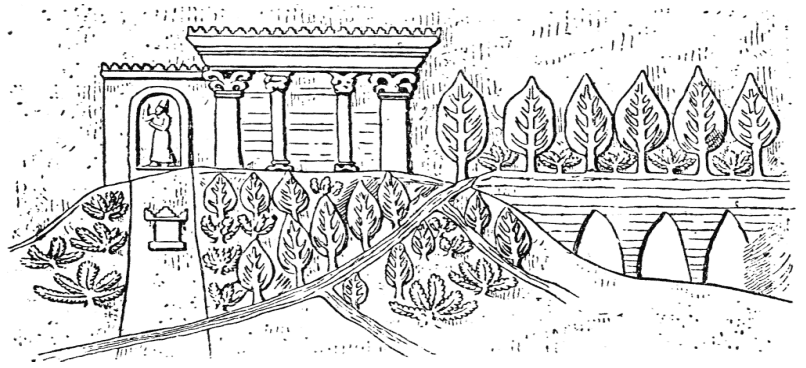

Fig. 2. This copy of a bas relief from the North Palace of

Ashurbanipal (669-631 BC) at Nineveh shows a luxurious garden watered by an aqueduct. [https://commons.

wikimedia.org/wiki/File:Hanging_Gardens_of_Babylon.gif]

landscape architecture [15] and its effects on European landscape design - works by E.H. Chang [3], X. Fang [5], Yu. Ivashko and S. Li [7], Q. Li [9], J. Lui [10]. Scientific publications by Y.-M.Allain and J.Christiany [1], A.Baraton [2] are devoted to French regular parks. Sources from the history of English landscape parks [16] and gardens of the period of constructivism-avantgarde, where Ye. Zabelina's publications became the basis $[17,18]$, were also studied.

The following methods were used: the method of historical analysis, the method of comparative analysis, the graphoanalytical method.

\section{Traditional gardens of Ancient Egypt, Assyria and China}

These civilizations formed their own approaches to landscape design, but they were all based on the exaltation of nature as the highest manifestation of harmony and beauty. The most ancient testimonies of the gardens of ancient Egypt include testimony related to the reign of the Pharaoh woman of the New Kingdom of Queen Hatshepsut (1490/1489 - 1468 BC, 1479 $1458 \mathrm{BC}$ or $1504-1482 \mathrm{BC}$ ), which contributed to the strengthening and prosperity of Egypt. The relief at the funeral temple of Hatshepsut in Deir el-Bahri depicts an expedition of five ships to the country of Punt in 1482 $1481 \mathrm{BC}$ for the transportation of the myrrh-trees of the Amiris and the planting at the temple for the worship of the god Amon. It is obvious that such a temple garden performed primarily a symbolic function.

Perhaps one of the most famous examples of a garden based on revealing the natural beauty of living plants was the hanging gardens of Semiramis in Babylon in the kingdom of Assyria - one of the world seven wonders (Fig. 1).

There are several legends that link the creation of the gardens to either the king of Babylon, Nebuchadnezzar $(605-562 \mathrm{BC})$, who allegedly arranged them for his wife, Amitis the princess of Lydia, or the queen, Semiramis, who ruled Babylon before Nebuchadnezzar more than 200 years earlier, in the 9th century BC. However, discussions about the reality of the Semiramis gardens existence are still ongoing. Some scholars adhere to the version that the Hanging Gardens were created by another king, the Assyrian king Sinnaherib (704-681 BC) in the capital of his Nineveh state.

According to the descriptions, the Hanging Gardens were at palace, the palace itself had very high walls supported by stone columns, and trees and plants were planted on the terraces so that the landscape looked like a mountainous country. The gardens were square in shape with a side close to 120 meters and the height of all tiers was about 60 meters. According to the chronicles, the arrangement of the gardens required great ingenuity, since the depth of each tier of the garden was such as to provide normal space for tree roots and water for irrigation was supplied from the Euphrates.

The Sennacherib garden was considered a miracle of its time not only because of the plants and trees beauty, but above all because of the hydrotechnics high level for supplying water to all terraces with plants. Sennacherib's grandson Ashurbanipal depicted a garden on one of the palace reliefs (Fig. 2).

Wherever the legendary garden was located, it can be noted that it performed both a utilitarian (ensuring contact with the natural environment, creating a favorable microclimate) and symbolic function (emphasizing the social status of the ruler). Despite the fact that the mass of artificial structures was much greater than the mass of natural components (plants), such a garden mimicked the natural environment, rather than opposing itself to it.

A distinctive style of landscaped gardens has emerged and over the course of three millennia formed in China, evolving into many varieties - imperial gardens, private gardens of famous people, gardens at temples and monasteries, public gardens. The main task of the garden in China was to create a mood of calm and harmony by idealizing the landscape with artistic means. The "joy of the park" is mentioned in the ancient Chinese canon of the Book of Songs. The characteristic Chinese garden was surrounded by walls and contained ponds, picturesque groups of stones, located in certain places small architectural forms - pavilions. The garden 
was planned in such a way that during the walk along the paths the viewer would discover elaborate species views in which nature was the main role, and architecture merely complemented it.

The planning of imperial gardens was especially careful. Thus, in 1267, an imperial park was established in Beijing, which had two artificial lakes. And in the eighteenth century, another Yíhé Yuán Yiheiuan Palace Park (Carefree Leisure or Harmony Conservation Park) was also built, with an artificial lake and an artificial hill, according to the traditional Chinese art genre "shang shui" ("mountain-water") as a traditional symbol of Universe creation.

In the 5 th -6 th centuries there was a division into imperial, private and public gardens. The main difference between the imperial gardens and the nonimperial gardens was immensity of the imperial ones and privacy of all others.

There were certain canons of arranging a traditional Chinese garden, the main one of which was the inability to simultaneously see the entire space of the garden, which "decomposed" into a series of separate spaces with species pictures and small architectural forms. Walking through the garden, a viewer watched the landscape change all the time. Such an inability to simultaneously view the entire expanse of the garden obeyed the ancient principles of "Feng Shui", according to which natural landscapes have a positive effect on human condition. According to the "Feng Shui", the specific partitioning of the spaces prevented evil spirits: in architecture this role was played by multi-folded malleable screens, in landscape art by natural elements such as hills or trees. Views from different points were considered separately - from the main entrance, during walks in the garden, even from neighboring areas.

Unlike the Ancient Egyptian and Assyrian gardens, which were based solely on aesthetic and hedonistic values, the Ancient China garden has, above all, a strong philosophical and religious foundation for Taoism, Buddhism, and Confucianism. The main difference between the Chinese garden, both Egyptian and Assyrian, and European English and French, was that the garden in China acted as a means of dialogue between nature and human as a cultural origin which did not involve human intervention in the natural environment. It was thought that although the garden is an artificial creation of human, it does emit light of the beauty of nature. The garden in China was considered in the context of three major ontological components of the world: Sky, Earth, and Human, and it was believed that the most complete person is realized in art. Unlike in Europe, in China, humans did not act as the supreme creation of God, empowered to change the world around themself and their needs, humans only improved the natural properties of things by means of their aesthetization. This approach of minimal interference with the natural properties of things implied the poetization of such elements that were not considered to be the bearers of aesthetic properties in European countries. For example, sacred boulders of the original form from the bottom of Lake Taihu, which outline their analogies with Taoist calligraphy, were used as the "best decoration" of the Chinese garden. It is interesting that these bizarre boulders with holes were not of the nature: stonecutters knocked holes in them and lowered to the bottom of the lake, and after years the water destroyed the traces of treatment and gave the holes a natural character.

Analyzing the rich content of the landscape views of many ancient Chinese gardens, one can see the borrowing of some ways of views creation from traditional Shang-shui paintings, which is also due to the fact that well-known artists sometimes worked to order as landscape designers.

The garden gradually expanded its features: to the picturesque landscapes, water masses, local greenery with exotic birds (garden-pleasure) were added such elements as stones for slides, brought from other countries trees and plants, complicated compositions of gardens, where they began to display miniature real lakes and mountains.

With each change in the dynasties, the role that relied on landscape gardening changed somewhat.

During the reign of the first emperor Qin Shi Huang a park was considered a prototype of the empire and was believed to have the same properties.

During the reign of the Han Dynasty, in addition to the function of the symbol of the socio-political system of China, parks and gardens are given an esoteric function, since this period is associated with the cult of immortal hsien (in Chinese Taoism - immortals who achieved divinity through devotion to Taoist practices and teachings) and immortality. In the Han parks and gardens, "divine mountains" appear where they are thought to live immortal, arbors are dedicated to the immortal, and slopes are sown with sacred plants.

Gradually, these tendencies move from imperial gardens to private and public gardens, but there they lose most of the social and esoteric component and in most cases are directed to the artistic enhancement of the natural environment by means of landscape design and small forms architecture.

Particularly flourishing of landscape art came from the Ming Dynasty, when having a garden of its own became a sign of a person's elite affiliation. In parallel, this causes the small forms of architecture to blossom when pavilions for different types of occupations are spread - for painting, music and singing, for reading, meditation, relaxation, tea parties, guest meetings. Gardens actually take on the role of an important character of poetic works and plays, and people travel to see the gardens described in literary works with their own eyes. A popular theme of painting of the Ming era is the landscapes of the gardens, written either at the request of the owner or in honor of an event.

Gradually, some varieties of gardens are formed large-scale imperial gardens of closed type, surrounded by walls and located over a large area, private gardens in estates - a small area, but with miniature views and 


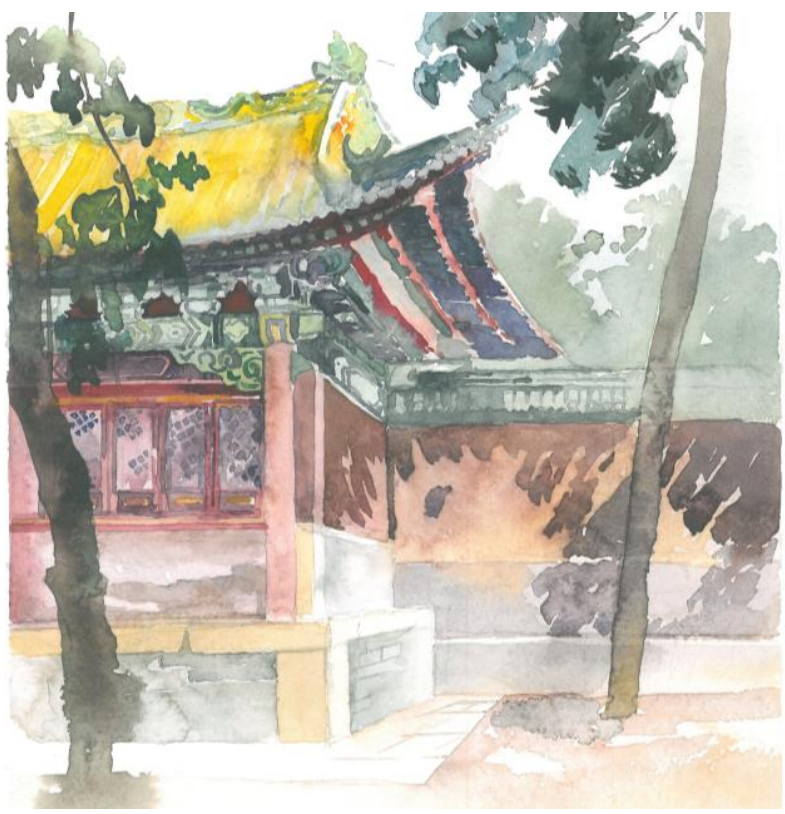

Fig. 3. Fow Anh Gong Pavilion of the Gugong Ensemble (Imperial Palace of the Ming and Qing Dynasties) in Beijing, China, [watercolor by Chang Peng, 2019]

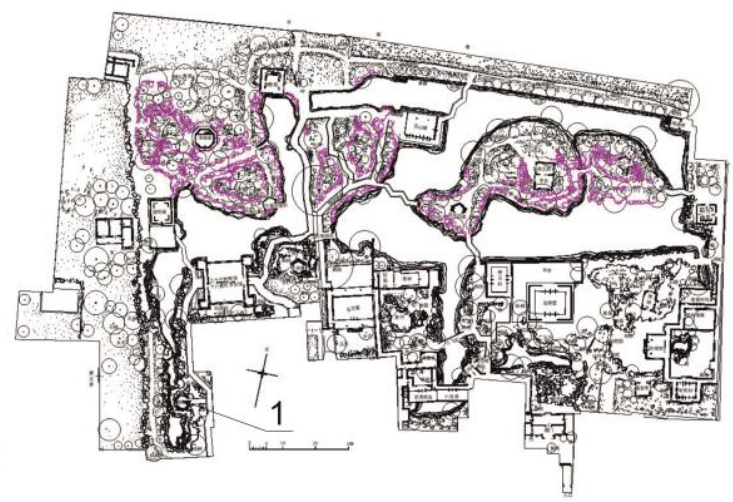

Fig. 4. An example of traditional privat Chinese garden"Zhuozheng yan" ("Garden of the retired official") in Suzhou: 1 - the arbour "Pavilion where you can see the shadow of the tower"

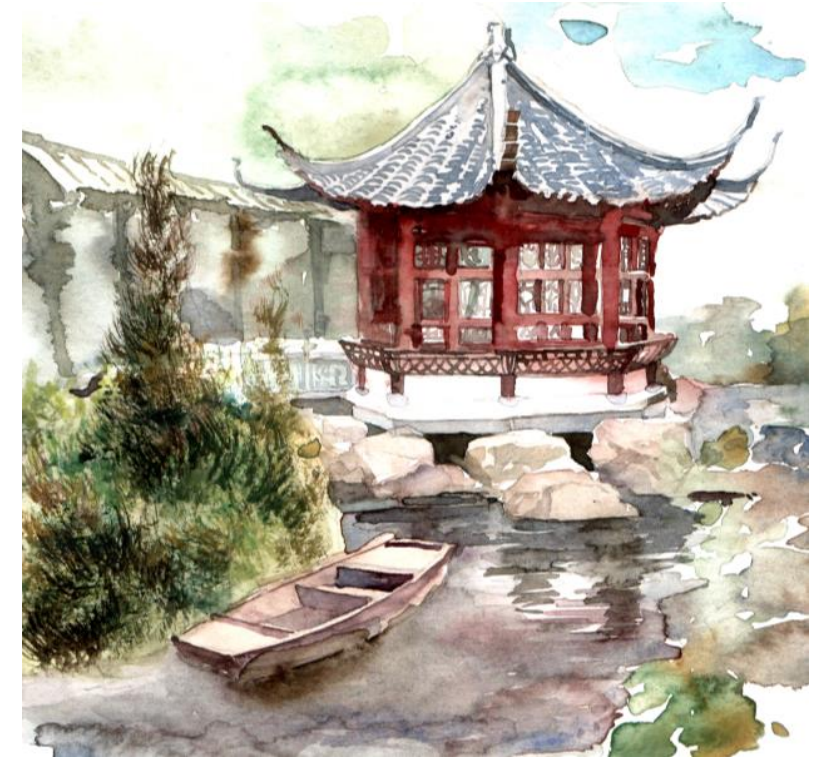

Fig. 5. "Pavilion where you can see the shadow of the tower" at "Zhuozheng yan" garden in Suzhou, China. [watercolor by Chang Peng, 2019] small landscape detail, public gardens for shared use, as well as natural gardens, as well as they were somewhat improved by enhancing the properties of the landscape and supplementing it with small architectural forms. The gardens at temples and monasteries, which were aimed at seclusion, meditation and the performance of religious rituals, were a separate type. Such gardens include the Tanjou and Zetai Gardens in Beijing, the Jin Temple Garden in Taiyuan in Shanxi, the Western Garden in Suzhou in Jiangsu, the Linxi Temple Garden near Xihu Lake in Hangzhou, Zhejiang Province, Weibamyao Garden in Chengde City, Hebei Province.

Temple and monastery gardens were distinguished by their increased size and in the area of the territory approached the imperial gardens, and their style provided the maximum naturalness of landscape views.

As Chinese architecture as a whole was shaped according to the social hierarchy, certain types of gardens were given some functional significance, in particular, the scale of the Imperial Garden site was another expression of the exclusive position of the Son of Heaven on Earth (Fig. 3). The area of such a garden could be at least several hundred hectares. Typical examples are the gardens at the Bishu Shanzhuang palace and park ensembles in Chengde City, Hebei Province, the "Gardens of Perfect Clarity", and Iheyuan Park at the "Three Mountains and Five Gardens" complex in Beijing.

The Bishu Shanzhuang ensemble originated in the early Qing era under Emperor Kangxi. The residence performed state functions and testified that the "heavens are squeezed by the emperor's bosom" with the richness of the layout and the appearance of the individual buildings.

In order to show all the grandeur and scale of the empire in one residence, to represent northern and southern landscape views within the same park, the area of lakes (modeled on the picturesque landscape of Jiannan with imitation of some well-known landscape paintings), the plains area (steppes of the Great Wall of China) and the mountain area (picturesque mountains of northern China) were distinguished.

The special role in creating the ideal of a private Chinese garden belonged to the city of Suzhou itself, which was due to many positive factors: the favorable climate of Suzhou, located south of Yangtze River on the shore of Lake Taihu, inhabited the East Chinese Jiangsu Province, the wealthy cities landscape gardens in private estates (Fig. 4, 5).

Thus, the landscape art of ancient civilizations was based on the maximum use of the nature aesthetics, although the share of artificial components in them could be quite high.

\section{French regular and English landscape park}

Although the concept of a regular park is associated with French parks, for the first time such parks appeared in Italy during the Renaissance (Boboli Gardens in Florence and Villa Medici Gardens in Fiesole) and were 
transferred to the French territory in the early sixteenth century. The French regular, or geometric, garden or park (fr. Jardin à la française) was characterized by geometrically correct layout, emphasized by the symmetry and regularity of the composition. This was expressed in straight allées, which at the same time played the role of axes of symmetry, geometrically correct outlines of parkers and flower beds, giving trees and shrubs crowns forms of various shapes by forming crowns. Art of regular parks reached its peak during the Baroque period in France, in the 17th and 18th centuries, and the most striking examples were the gardens of Versailles, commissioned by King Louis XIV by landscape architect André Le Nôtre. This is when regular parks become an integral part of palace complexes. A specific system of terms for the regular garden components has also been formed. These include, in particular, a parterre for viewing from above, from the palace windows (square or rectangular, with ornamentation of low-cut ornamental plants and backfill of multicolored gravel or large fraction sand), a lawn parterre (with sod placed according to the design ornament and sand filling), a broderie (an ornamental garden made of sheared box hedges), a bosquet (a formal plantation of trees, set in strict regularity), an allée (a straight path or road with a line of trees or large shrubs running along each side), topiary (a specially trimmed shrub or tree, usually geometric in shape), patte d'oie (three or five allées (tracks) that come from one point).

With the decline of baroque and rococo fashion as opposed to the regular French park of Le Nôtre in the eighteenth century, an English landscape irregular park emerges. The promotion of these traditions as an embodiment of natural aesthetics was greatly facilitated by Jean-Jacques Rousseau, who re-designed in English style his garden in Ermenonville.

French and English parks expressed different canons of aesthetics in landscaping, having at the heart of a clearly philosophical idea - either the dominance of human over nature (French park), or the recognition of nature as the highest criterion of aesthetics (English park).

Although it is believed that the first landscape architects who laid foundations for English garden formation - William Kent and Charles Bridgman - were inspired by the landscapes of Poussin and Lorraine, but it would be desirable to pay attention to the influence of Chinese gardening traditions in this process, when in the wave of admiration for Chinese culture, the admiration for Chinese landscape gardening traditions and small Chinesestyle architectural forms gradually emerges. In scientific sources we can find the characteristics of the English landscape park: emphasizing the natural aesthetics of the species pictures, lack of inspection of the whole park from afar, elements of unpredictability and surprises when a pavilion, grotto, lake or sculpture was hidden behind every turn of the alley. All this is combined with an intersection of Chinese elements (for example, Chinoiserie motifs were used by William Chambers in Kew Gardens).
In the second half of the eighteenth century, the most successful landscape architects of England became Lancelot Brown and Humphrey Repton, who finally abandoned the geometry of the park layout, the channels masked at small streams, used species pictures in the form of lawns with picturesque groups of trees. It is Humphrey Repton formulated the main features of a landscape park, based on free planning, use of natural landscapes features and improvement of their beauty, maximum naturalness of landscape compositions, integrity the garden elements, the secondaryity of architectural buildings and their subordination to the landscape in size. Inequality of terrain and presence of natural reservoirs are perceived as positive features. If the site terrain is uniform and flat, it is necessary to diversify it by filling artificial hills and arranging reservoirs and artificial ravines.

But on the same principles, traditional Chinese gardens have been created for thousands of years! Given that regular gardens were widely spread in Europe (emerged in the Renaissance period in Italy), and the aesthetic principles of landscape parks were not mentioned until the eighteenth century, it is possible to conclude that these processes continued in the period of admiration for Chinese culture. Significantly, through millennia of tea traditions, a keen interest in porcelain utensils, screens and small accessories, Europe became interested in Chinese culture as a whole, this fascination gradually extended to traditional painting, philosophical and esoteric teachings, and landscape architecture. Following the model of the Chinese pavilions, "oriental" arbors and so-called "tea houses" began to be built, and this gradually led to a total rethinking of the whole concept of a regular garden.

Thus, it is possible to draw analogies between how Chinese culture, from the seventeenth century, first through the realm of everyday life, and then at $\mathrm{n}$ cultural and artistic traditions, and how similarly Japanese culture from the second half of the nineteenth century gradually influenced the European and American culture, creatively "sprouted" in the European interpretation in the paintings of the Pre-Raphaelites, graphics and painters of the era of Impressionism and Modernism, became one of the origins of the modernist style and "prairie style" of F.L. Wright, highlighted in a number of publications by Mykola Orlenko, Yulia Ivashko and Shuang Li $[7 ; 13]$.

The rapid development of cities in the second half of the 19th - early 20th century exacerbated the problem of providing favorable living conditions for most citizens. It has become clear that a traditional garden / park surrounded by densely populated neighborhoods cannot solve this problem. There is an active search for alternatives - from the concept of the garden city of Ebenizer Howard to the modernist concept of creating a system of continuous urban landscaping. In this way, the utilitarian function of a traditional garden / park seems to be "detached" from it and can be realized by other objects. 
1920s gardens of Cubism as a challenge to the millennial traditional approach in landscape design

It was in the 1920s, after the First World War, after the revolutions, social upheavals, and the pandemic of the "Spanish flu" that the foundations of new social relations, new art, and new architecture were formed. Landscape architecture was no exception.

Such modern views of the garden as a work of art and design did not emerge in 1920s, but much earlier, at the beginning of the twentieth century, and a significant role in this process was played by modernist artists P. Picasso, E. Matisse, P. Mondrian, V.Kandinsky, K.Malevich.

In concentrated form, new trends were put into practice in the gardens of the 1920s, dubbed "cubist" or "architectural". Landscape design, as in art in general, also showed cubism, which is characterized by geometric shapes, the decomposition of a three-dimensional object into simple elements and its simultaneous image from different sides. Cubism concentrated on a flat twodimensional plane of the surface, while rejecting traditional images of linear perspective, light-shadow relationships, and traditional imitation of the natural environment.

Cubists opposed the centuries-old tradition of threedimensionality with a vanguard system of constructing images from two-dimensional fragments, when an object or a person was depicted from several points at once.

Scientific sources on 1920's avant-garde / constructivism draw attention to manifestations of a new style in urban planning, architecture and design, but much less frequently to mention avant-garde manifestations in landscape gardening and landscaping.

The avant-gardism of Cubism was based on a fundamentally new philosophy, expressed by P. Mondrian in one expression: "In order to approach the spiritual in art, one must at least imitate reality, because the real is the opposite of the spiritual."

Mondrian, who was originally considered to be a representative of high Cubism, later created a concept of a new style called neoplasticism, which defined the means of expressing aesthetics - four-dimensional space, limited by simple lines and shapes and three primary colors (red, yellow, blue).

It was these ideas of neoplasticism that were embraced by landscape designers, in particular, in the geometry of neoplasticism, they see the origins of designing hardwood floors and gardens, where architecture became not an artificial addition to the natural environment, but became equal to it.

Although in the 1920s architecture was affected by new trends of the avant-garde, landscaping even at that time retained conservatism, two standards of the park or garden were recognized - English irregular, picturesque, and French regular, with symmetrical arrangement of tracks, flowerbeds and clear lines.

That is why a landmark event in the dissemination of innovative ideas in landscaping was the holding in 1925 in Paris of the International Exhibition of Contemporary Decorative and Industrial Arts, which was presented by the French avant-garde school project Robert Mallet-Stevens

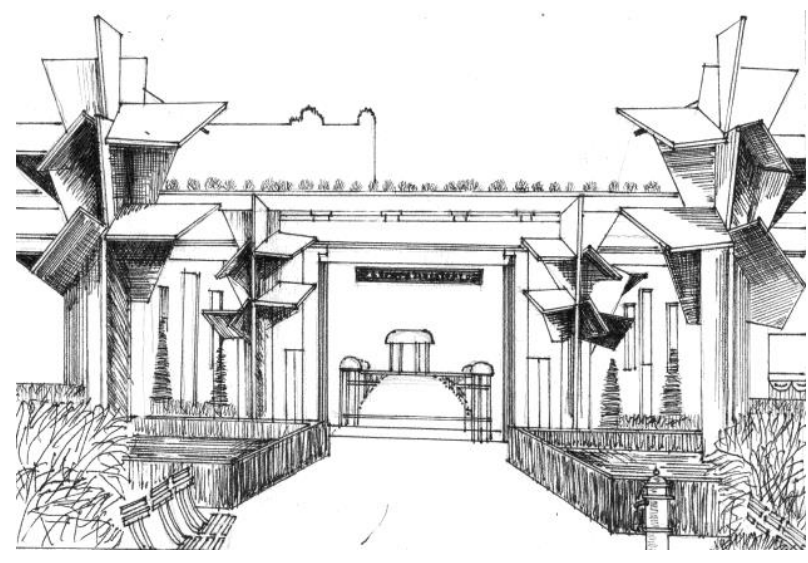

Fig. 6. "Jardin de l'habitation" by Robert Mallet-Stevens at the International Exhibition of Modern Decorative and Industrial Arts, Paris, France, 1925. [graphics by T. Kuzmenko]

garden of grass and concrete Jardin de l'habitation, where on four four-angle low platforms-flowerbeds there were four trees of reinforced concrete $4.5 \mathrm{~m}$ high (Fig. 6).

It is striking that the architect repeated the traditional layout techniques of the classic French garden, introducing such elements as regular planning, entrance arch, main central alley, along which were placed concrete trees. This example was analyzed in detail by architect Yelena Zabelina, who described him as one of the largest representatives of modernism alongside Le Corbusier, while noting the non-identity of the two representatives of the French Espry Nouveau, where for Le Corbusier, function and construction were more important, and for Mallet-Stephens - the aesthetics of structures and elements $[17 ; 18]$.

This synthesis of functionality, constructiveness of form and aesthetic component just demonstrated the garden at the exhibition, located on an inconvenient site in the Eastern part of the Esplanade des Invalides over railway tracks with engineering networks. In fact, as noted by Ye. Zabelina, the presence of an elevated platform was forced to close communications from above. The replacement of living trees with reinforced concrete sculpture trees (Fig. 7) also became a forced measure, since the exhibition took place in June, which made it impossible to transplant adult trees of the same height [17].

It did not do without living plants, although here they played a clearly secondary role: under the concrete trees a lawn of grass and the so-called "stone roses"-houseleeks (Sempervium) were arranged.

The bold creative experiment of the architect found both ardent supporters in the faces of Italian futurists and critics - mostly French landscape designers who did not take such a radical rethinking of the traditional French regular garden.

Unfortunately, this garden was only an exhibit and was dismantled after the exhibition ended. Ye. Zabelina draws attention to an interesting fact: many of the photos are posed by models in the toilets by artist Sonya Delone, which also testifies to the resonance that caused this garden. 


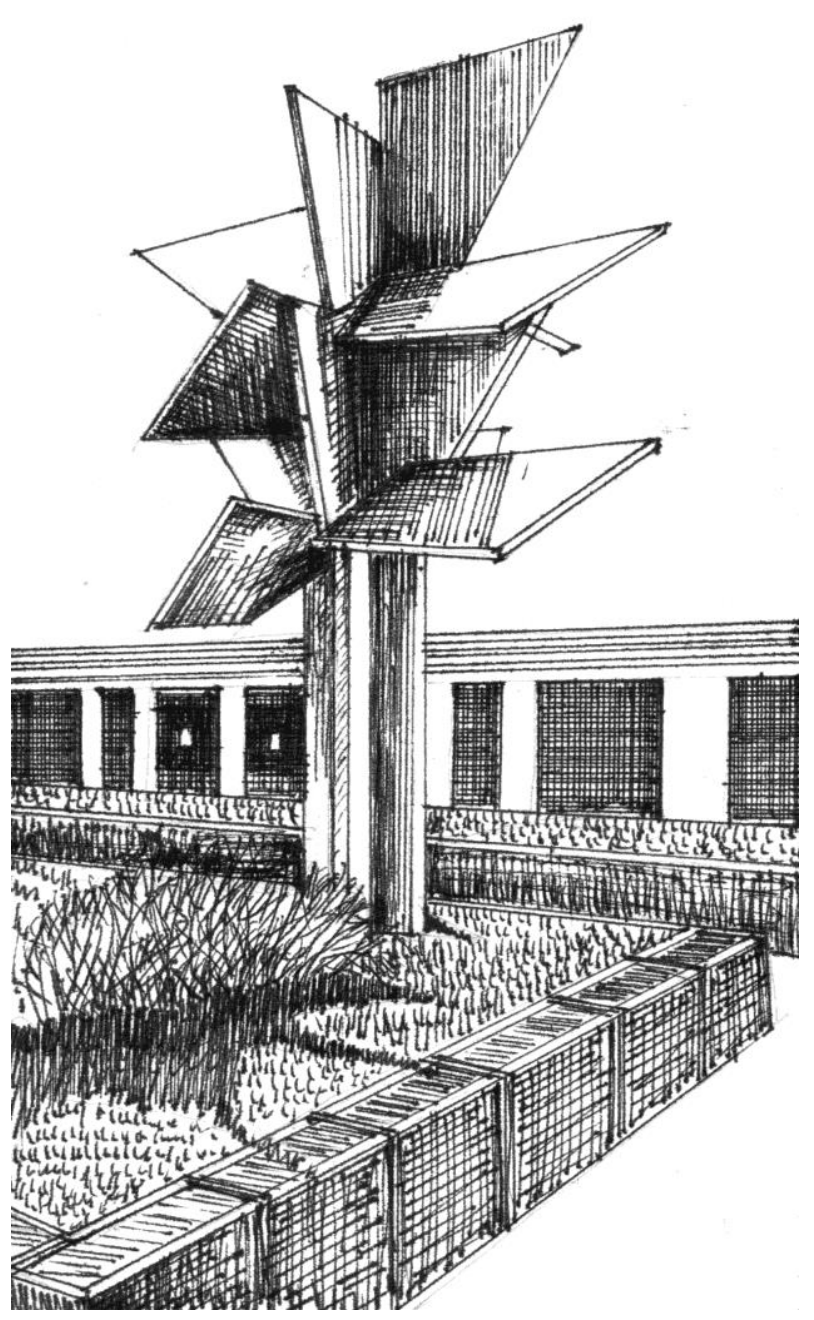

Fig. 7. Tree of reinforced concrete at the "Jardin de l'habitation" [graphics by T. Kuzmenko]

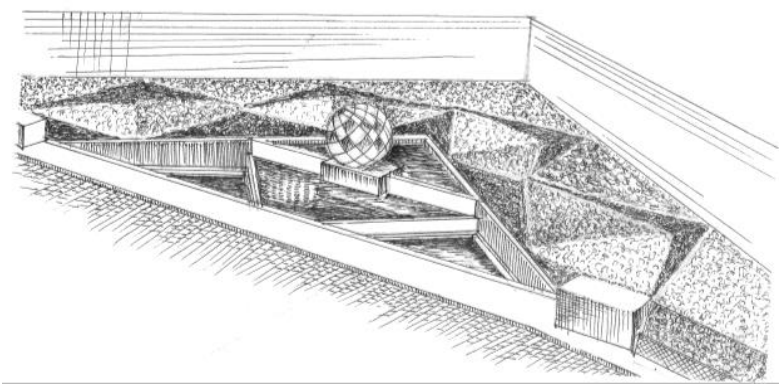

Fig. 8. "Garden of water and light" by G. Guevrekian at the International Exhibition of Modern Decorative and Industrial Arts, Paris, France, 1925. [graphics by A. Dmytrenko]

She believes that in reality the role of the MalletStevens garden has proved to be much more multifaceted than the avant-garde object, and suggests analyzing it as an embodiment of art synthesis. Recalling the affilation of Mallet-Stevens to the cinema group, she compares the posing of models in avant-garde toilets against the backdrop of concrete trees with movie footage with thoughtful scenes and plot.

The second landmark project that accelerated the changes in landscape design was the project "Garden of Water and Light" presented by Gabriel Guevrekian, which was also dominated by simple geometry of artificial shapes of triangular flower beds, quadrangular structures and triangles of mirror glass and water (Fig. 8). The garden at the exhibition is located on the Esplanade des Invalides.

The architect deliberately rejected traditional gardening techniques, instead using the aesthetic possibilities of the rotating mirror-stained-glass sphere. Such independence from the seasonality of plants (from July to October, the time of the exhibition) was achieved by the composition dominance not of living plants, but of glass and concrete. Despite the small area of the plot, the garden did not seem small due to the original three-dimensional flower beds.

The idea of a garden based on a combination of simple geometric shapes also was embodied by Gabriel Guevrekian in the Cubist garden at Villa Noailles.

At the heart of the garden plan, which became the embodiment of Cubism in the arts, is the triangle on which the square ledges are placed.

Significantly, in this landscape composition, living plants play a secondary role, subordinating to the design elements, and thus creating direct analogies with the Mondrian canvases and the earlier project "Garden of water and light", which was the reason for the invitation to design a garden in the villa in the city of Hyères. It is significant that the villa was designed by R. MalletStevens, so it is obvious that the avant-garde laconic architecture had to be enhanced by the same avant-garde garden at it.

Again, it is reasonable to compare the design of the garden at Villa Noailles with the black and white cinematography.

Such a comparison is all the more justified in view of the fact that R.Malle-Stephens participated in the creation of the avant-garde film scenery and at the same time authored the avant-garde villa project in the city of Hyères [17].

G. Guevrekian supplemented the villa's garden architecture with several optical effects, to which Ye. Zabelina also drew attention [17; 18]. It is significant that when planning the plot, the architect used a clear mathematical construction and on this basis created the illusion of perspective: from the side of the triangle base the garden seems longer than it really is, and from most points of view is not perceived as triangular in plan (Fig. 10). Although Cubist gardens are defined as a juxtaposition of the classic landscape design of previous centuries, in our view, they have reimagined in the new tradition and new material the features of French regular Baroque gardens. Thus, the French regular garden was also based on the principles of geometry with the dominance of straight lines, correct geometric shapes, and the regulated placement of living plants in accordance with the geometry of the composition of the garden or park, as well as the geometric forms of sheared crowns should express the dominance of human over nature. When designing a garden or park plan, it was possible to review it completely, in the long term, taking into account the laws of perspective and optics. In the Baroque days in France the garden became a place of performance, where performances, fireworks and balls were held. 


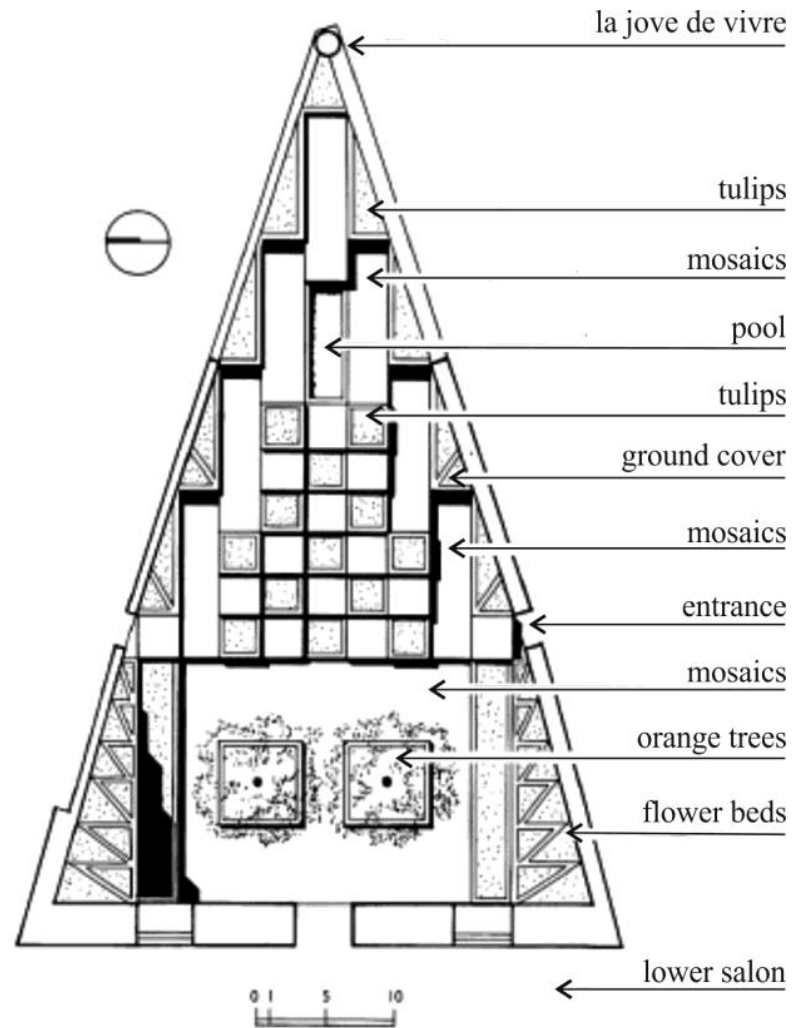

Fig. 9. Annotated layout of the garden at the Villa Noailles. Reconstruction by Dorothée Imbert after Agnès Fuzibet, Cécile Briole

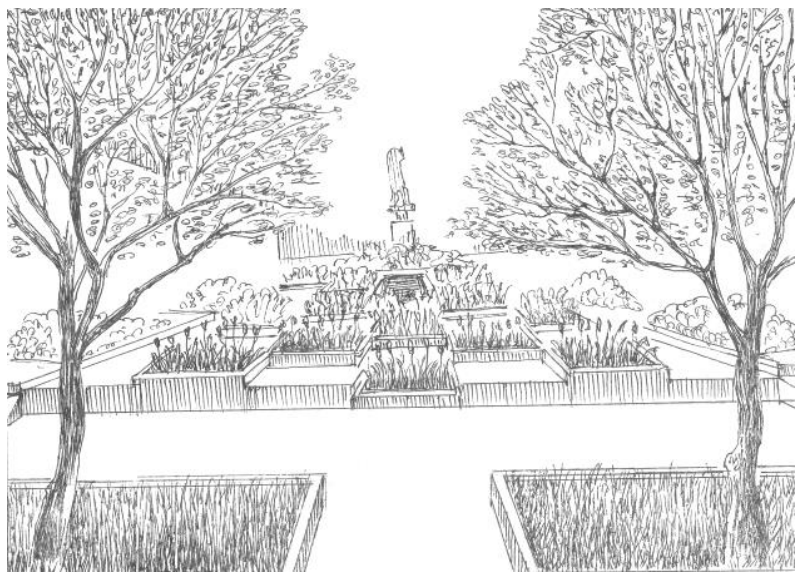

Fig. 10. The garden by G. Guevrekian at the Villa Noailles. View from lower salon [graphics by A. Dmytrenko]

Now let us analyze how these signs of a regular garden "sprouted" in the Cubist garden of the 1920s, in order to understand that the appearance of such a garden in France was not an accident. The avant-garde garden is also built on the basis of clear geometry, it is dominated by straight lines, each element - or flowerbed, or design element - is subject to a clear geometric arrangement, and the components of the garden have a delineated correct geometric shape (the difference from French regular gardens is the absence of ovals, curves and circles). The dominance of design elements over greenery also expresses the triumph of human over nature, in some cases it is actually a "Garden without plants". The garden of Cubism can be transformed into an element of performance (it is worth mentioning the fashion show against the backdrop of the avant-garde of R. MalletStevens). In addition, such gardens were immediately planned with the possibility of their complete inspection, creating perspectives and in some cases - an optical illusion of increasing size (as in the garden of the Villa Noailles).

\section{Modern "green architecture" and its relationship to landscape design}

The influence of "gardens of Cubism" on the park concept development is difficult to overestimate. If the park was traditionally considered as part of a cultivated natural environment, where the percentage of greening was much higher than the city average, the 20th century was marked by the emergence of theme parks (amusement parks, sports parks, etc.), which do not stand out among the urban environment. A typical example is La Villette Park in Paris, opened in 1986, where architectural objects play a leading role.

At the same time, landscaping is becoming more and more decentralized, approaching the places of concentration of people - residential, public and industrial buildings.

Greening of roofs, vertical greening of facades and the presence of fairly large green spaces inside buildings (for example, conservatories in the building of the Commerzbank in Frankfurt am Main, Germany) - all this blurs the line between building architecture and landscaping.

In turn, it should be noted that the architectural environment, as "second nature" continues to replace the "first nature" and inevitably takes over the functions of the natural environment. The creation of biotopes is becoming not just a whim, but an urgent need, for example, when designing a system of precipitation removal from urban areas.

At the same time, the objects of the architectural environment - the so-called smart buildings - get the ability to respond to changes in the environment like plants (turn on and off the heating, adjust the sun protection elements or open and close windows depending on wind speed and temperature, as is the so-called "Gherkin" - the skyscraper on the 30 St. Mary Axe in London). This blurs the line between artificial and natural environments.

\section{Conclusion}

A brief overview of the landscape design emergence and development from traditional approaches to the avant-garde of the $1920 \mathrm{~s}$ and the denial of the dominance of the natural component in landscape art demonstrates the different approaches that have been used in gardens and parks since ancient times. In ancient Egypt, the planting of sacred gardens near the temples was considered a worship of the gods, and mention of such expeditions to the rare trees were placed in the images on the walls of the temples. In Assyria gardens were created for aesthetic impression and enjoyment, gardens at the palaces of the rulers became the wonders of the world, along with architectural buildings, 
because they needed a sophisticated engineering system for watering for irrigation, arranging the right place for planting trees. China's landscape gardening, based on a combination of Taoism, Buddhism, and Feng Shui principles, has gone its own way. In China, in the early stages of gardening, the garden was considered a reduced model of the Universe structure, a synthesis of the harmonious combination of nature and human in the infinite space (these functions were not performed by the gardens of ancient Egypt and Assyria, intended either to honor the gods) or to worship the gods.

A revolutionary breakthrough in landscape design occurred during the period of constructivism, avantguard of the 1920s, when the role of human in the process of intervention in the natural environment is rethought, the garden is transformed into a certain installation, its layout is subordinated to clear geometry, and the place of living trees is occupied by trees while living plants are transformed into a certain neutral background in artificially created objects. The main goal of a Cubist garden is maximum expression of threedimensional bulk elements geometry, introducing glass surfaces as an important theme.

Landscape design began to be seen not as a subordination of aesthetics and beauty regularities in natural elements, but as a synthesis of the arts, which, along with a natural component, devoid of dominant importance, takes advantage of the aesthetic possibilities of sculptural compositions, elements of design and installations that are ignited in space and time. On the example of R. Mallet-Stevens' garden were models of avant-garde clothing were photographed, we can prove that the aesthetic means also added performance, when the style of clothing models correspond to the stylistics of landscape design.

It was in cubism that the concept of the garden practically envisaged the emergence of a modern garden without living plants, such as Martha Schwartz's "Garden Design Collage" made of synthetic materials on the roof of the Cambridge Microbiological Research Centre.

The current state of landscape design and architecture is characterized, on the one hand, by "detachment" from the objects of their traditional functions (i.e. providing a favourable microclimate and communication with the environment can be provided by objects other than the garden / park, so the garden can be completely deprived of living plants), and on the other the blurring of previously clear boundaries between landscaping and installation, landscaping and architecture, between artificial and natural environment $[6 ; 8]$.

Of course, the turning point in changing the traditional paradigm of landscape architecture is the socalled "gardens of Cubism", the impact of which on the further development of landscape design is difficult to overestimate.

\section{References}

1. Allain, Y.-M., Christiany, J. L'art des jardins en Europe. Paris: Citadelles et Mazenod, 2006.

2. Baraton, A. Walks in the gardens of Versailles. Paris: Artlys, 2010.

3. Chang, E. H. Britain's Chinese eye: Literature, empire, and aesthetics in nineteenth-century Britain. Stanford: Stanford University Press, 2010.

4. Curl, J. S. A Dictionary of Architecture and Landscape Architecture, Oxford : Oxford University Press, 2007.

5. Фан, С. Лучшие Китайские сады. Москва: Арт-родник, 2010. (Fang, X. Best Chinese Gardens. Moscow: Art-rodnik, 2010.)

6. Івашко, О.Д. Філософія сучасного арт-простору. Матеріали II Всеукраӥнської наукової конферениї «Філософія науки, техніки і архітектури в гуманістичному вимірі». Київ,2018. C.186-187. (Ivashko, O.D. Philosophy of modern art space. Proceedings of the 2nd All-Ukrainian Scientific Conference "Philosophy of Science, Technology and Architecture in the Humanistic Dimension". Kyiv, 2018, p. 186-187.)

7. Ивашко, Ю.В., Ли, Ш. Модерн Западной Европы, Украины и Китая: пути трансформации и имплементации. Киев: Феникс, 2015. (Ivashko, Yu.V., Li, S. Art Nouveau of Western Europe, Ukraine and China: ways of transformation and implementation. Kyiv: Phoenix, 2015.)

8. Iwaszko O. Społeczna Przyroda Nowych Artystycznych kierunków w Miejskim Środowisku. Przestrzeń /Urbanistyka/ Architektura, 2/2018, s. 167-176.

9. Li, Q. Chinese pavilions. The Series of 100 Gems of Chinese Architecture. China Architecture and Building press, 2019.

10. Люй, Ц. Скульптурные парки в современном Китае: проблемы оригинальности и перспективы эволюции. Вестник Санкт-Петербургского университета, серия Искусствоведение, 2017, №7 (3), c. 360 - 372. (Lui, J. Sculpture parks in modern China: problems of originality and perspectives of evolution, Bulletin of St. Petersburg University, Art History Series, 2017, No 7 (3), p. 360 - 372.)

11. Oleksiichenko, N., Gatalska, N., Mavko, M. et. al. The role of woody plants in the formation of figurative and symbolic structure of memorial parks. Landscape Architecture and Art, 2019, vol. 14, p. 78 - 88.

12. Oleksiichenko, N., Gatalska, N., Mavko, M. Theoretical and methodological principles of memorial parks threedimensional composition and ideological lines expressing means complex assessment. Landscape Architecture and Art, 2018, vol. 12 , p. $22-32$.

13. Орленко Н., Ивашко Ю., Ли Ш. Реинкарнация северного национального романтизма. Исследование и опыт реставрации объектов. Киев: Феникс, 2016. (Orlenko N., Ivashko Yu., Li S. The reincarnation of northern national romanticism. Research and experience in restoration of objects. Kyiv: Phoenix, 2016.)

14. Polat, A., T., Akay, A. Relationships between the visual preferences of urban recreation area users and various landscape design elements. Urban Forestry \& Urban Greening, 2015, vol. 14(3), p. 573 - 582.

15. The art of Chinese pavilions. Beijing: Foreign Languages Press, 2006.

16. The English Garden. London: Phaidon Press, 2008. 
17. Забелина, Е., В. Сад бетонныхх деревьев Малле-Стевенса [online 14.03.20]. https://gardener.ru/library/ article/page4176.php (Zabelina, Ye. V. Malle-Stevens' Concrete Tree Garden [online 14.03.20]. https://gardener.ru/library/ article/page4176.php)

18. Забелина, Е.В. Поиск новых форм в ландшафтной архитектуре. Москва: Архитектура-С,2005. (Zabelina, Ye.V. Search for new forms in landscape architecture. Moscow: Arkhitektura-S, 2005.)

AUTHORS:

Mykola Dyomin. An urbanist and landscape architect. Doctor of Architecture, Professor, Professor, Vice-president of Ukrainian Academy of Architecture. Kyiv National University of Construction and Architecture, 31, Povitroflotskyi Avenue, Kyiv, Ukraine. E-mail: yulia-ivashko@ukr.net

Denys Chernyshev is a specialist in biosphere compatibility and environmental architecture, Doctor of Technical Sciences (2019), Professor (2015). Kyiv National University of Construction and Architecture 31, Povitroflotskyi Avenue, Kyiv; E-mail: denis01011978@ukr.net

Andrii Dmytrenko. An urbanist and landscape architect. Candidate of Technical Sciences (Ph.D.), Associate Professor. National University "Yuri Kondratyuk Poltava Polytechnic", Educational and Scientific Institute of Construction and Architecture, 24, Pervomaiskyi Avenue, Poltava, Ukraine. E-mail: metr5555@ukr.net

Tetiana Kuzmenko. An urbanist and landscape architect. Candidate of Architecture (Ph.D.) (2018), Associate Professor. National University "Yuri Kondratyuk Poltava Polytechnic", Educational and Scientific Institute of Architecture and Construction, 24, Pervomaiskyi Avenue, Poltava, Ukraine. E-mail: tancho286@gmail.com

Peng Chang. Post-graduate student, Kyiv National University of Construction and Architecture, 31, Povitroflotskyi Avenue, Kyiv, Ukraine. E-mail: changpeng2277@gmail.com

Kopsavilkums. Rakstā analizēti un pētīti paṇēmieni, kā no tradicionālas ainavas, pamatojoties uz avangarda uz kubisma principiem un uzskatiem, ainavtelpa dinamiski mainījusies. Pētīts ainavtelpas pārmaiņu periods 20. gadsimta sākumā. Ķīniešu dārzā un dabiskajā vidē arhitektūrai bija otršķirīga loma, tikai uzsverot ainavas skaistumu un vizuāli estētiskās kvalitātes. Dabiskā vide diktēja nelielu arhitektūras formu izskatu paviljonus un lapenes, to izmērus, siluetus un koloristiskos risinājumus. Maksimālā dabas ainavu saglabāšana bez cilvēka iejaukšanās bija vērsta uz tā dēvēto ainavu angḷu dārzu. Kopumā rakstā izvērtēti dažādi dārza stili, kas pie konkrētiem apstākḷiem nodrošināja konkrētu plānošanas veidu, ieviešot izmaiņas pilsētplānošanā un ainavu dizainā. 